\title{
FUNGSI DAN PERANAN BATU BERGORES DALAM TRADISI MEGALITIK : STUDI KASUS TEMUAN DI PROVINSI LAMPUNG
}

\author{
FUNCTION AND ROLE OF STONE GORGE \\ IN MEGALITIC TRADITION:
}

Case Study Findings in Lampung Province

\author{
Nurul Laili \\ Balai Arkeologi Jawa Barat \\ Jl. Raya Cinunuk KM 17 Cileunyi, Bandung \\ E-mail: nurul.laili@kemdikbud@go.id
}

\begin{abstract}
This study puts forward the problems about the function and role of stones in the megalithic tradition. The purpose of this study reveals the existence of scratched stones and their role in a megalithic site. The function and role of bergores stones in the Lampung region can not be separated from the element of worship. Scratched stones are always associated with other findings, namely menhirs, dolmen, flat stones, and sequential stones. Desires and expectations from supporters of megalithic culture to gain strength from ancestral spirits treat bergores stone as one of the complementary means of worship other than other types of megaliths. The form of visualization of interactions carried out with ancestral spirits is poured in the form of scratches.
\end{abstract}

Keywords: scratched stone, megalithic tradition, function, worship

\begin{abstract}
Abstrak
Kajian ini mengkedepankan permasalahan tentang fungsi dan peranan batu bergores dalam tradisi megalitik. Tujuan dari kajian ini mengungkap keberadaan batu bergores dan peranannya dalam suatu situs megalitik. Fungsi dan peranan batu bergores di kawasan Lampung tidak terlepas dengan unsur pemujaan. Batu bergores selalu berasosiasi dengan temuan lainnya, yaitu menhir, dolmen, batu datar, dan batu berurut. Keinginan dan pengharapan dari pendukung budaya megalitik untuk mendapatkan kekuatan dari arwah leluhur memperlakukan batu bergores sebagai salah satu pelengkap dalam sarana pemujaan selain jenis megalitik lain. Bentuk visualisasi dari interaksi yang dilakukan dengan arwah leluhur dituangkan dalam bentuk goresan.
\end{abstract}

Kata Kunci: batu bergores,tradisi megalitik, fungsi, pemujaan 


\section{PENDAHULUAN}

Kawasan Lampung termasuk daerah yang banyak mempunyai situs megalitik. Temuan yang diperoleh di setiap situs sangat beragam, seperti temuan megalitik di daerah lain, kawasan Lampung juga diperoleh antara lain dolmen, batu datar, batu berurut, menhir, batu kandang, dan batu bergores.

Batu bergores yang dimaksud dalam tulisan ini adalah pahatan atau goresan pada temuan yang merupakan bagian dari tradisi megalitik. Wujud dari batu bergores berupa (1) monolit yang dipahat/gores; (2) jenis temuan megalitik lain (menhir, batu datar, dolmen yang terdapat pahatan/ goresan).

Situs-situs megalitik di Indonesia yang memiliki tinggalan batu bergores, adalah Banyuurip (Purworejo, Jawa Tengah), Sumurpule (Rembang, Jawa Tengah), Bada (Sulawesi Tengah), Cicurug (Sukabumi, Jawa Barat), Cabangdua (Lampung Barat?), Bojong, dan Pugungraharjo (Lampung Tengah), Limbanang Atas ( Sumatera Barat), Tegurwangi Lama(Lahat, Sumatera Selatan ), Pandeglang (Banten), dan Watu Pinawetengan (Sulawesi Utara) (Haris Sukendar, 1979: 15; 1997/1998: 59-69; Anwar Falah, 1994: 25).

Fenomena yang ada menunjukkan temuan batu bergores secara kuantitatif merupakan temuan yang jauh lebih sedikit dibanding temuan megalitik lainnya. Untuk kawasan Lampung, batu bergores merupakan temuan paling minim dibanding temuan menhir, dolmen, ataupun batu datar. Di sebagian besar situs megalitik, temuan batu bergores selalu berasosiasi dengan temuan megalitik lainnya.
Situs-situs batu bergores di kawasan Lampung berada di

1. Kabupaten Lampung Timur, yaitu Situs Bojong, Benteng Nibung, dan Pugungraharjo

2. Kabupten Lampung Barat, yaitu Pekon Balak, Air Ringkih, dan Sukarame

Keberadaan batu bergores dalam tradisi megalitik tentunya mengandung maksud-maksud tertentu. Demikian pula halnya dengan pahatan/goresan yang ditorehkan pada sebuah batu dapat dipastikan mempunyai tujuan. Oleh karena itu, dalam kajian ini perlu dikedepankan permasalahan tentang apa fungsi dan peranan batu bergores dalam tradisi megalitik. Hal ini menjadi lebih menarik, karena temuan batu bergores paling sedikit dibanding temuan bangunan megalitik lainnya.

Tujuan dari kajian ini diharapkan dapat lebih mengungkap keberadaan batu bergores dan peranannya dalam suatu situs megalitik. Dengan demikian akan dapat diketahui kontribusi batu bergores dalam setiap situs megalitik.

\section{HASIL DAN PEMBAHASAN \\ TINGGALAN BATU BERGORES LAMPUNG}

\section{Situs Bojong}

Situs ini terletak di Desa Wana, Kecamatan Perwakilan Melinting, Kabupaten Lampung Timur.Situs diteliti pertama kali oleh tim Balai Arkeologi Bandung. Saat itu wilayah Wana termasuk Kabupaten Lampung Tengah (Falah, 1994: 25). Lahan situs ini merupakan lahan kebun lada yang dikelilingi oleh sungai 
kecil dan sawah rawa-rawa. Tinggalan yang diperoleh berupa batu berurut (stone avenue), batu bergores, dan dolmen.

Batu berurut berjumlah 45 batu dengan jarak berkisar antara 2-6 meter dari satu batu ke batu lainnya. Di bagian pertengahan batu berurut terdapat beberapa batu bergores.Batu bergores di situs ini merupakan batu monolit. Di sekitar batubatu bergores tersebut, terdapat susunan batu-batu yang diperkirakan susunan batu temu gelang (stone enclosure).

Torehan dalam batu bergores merupakan alur-alur bekas asahan yang terdapat pada bagian permukaan. Banyaknya alur bekas asahan di setiap batu bergores beragam, dari satu torehan sampai lebih. Bentuk goresan merupakan garis-garis lurus yang tidak beraturan.

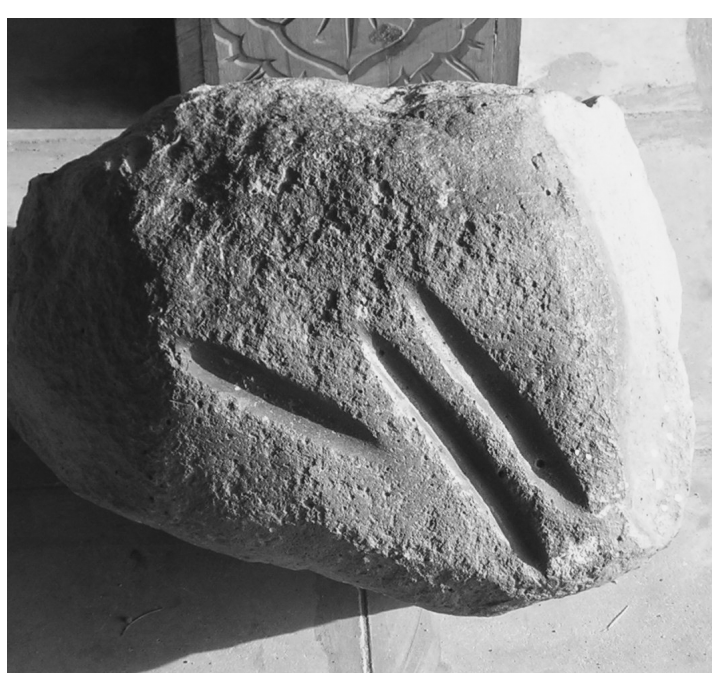

Gambar 1. Salah satu bentuk batu bergores yang ditemukan di daerah Lampung

(Sumber: Dokumen Balai Arkeologi Bandung, 1998)

\section{BENTENG NIBUNG}

Lokasi situs berada di Desa Wana, Kecamatan Perwakilan Melinting,
Kabupaten Lampung Timur. Situs ini beberapa kali telah diteliti oleh beberapa ahli. Penelitian yang Balai Arkeologi Bandung dilakukan pada tahun 1998 (Yondri, 1998: 7 -- 20). Saat ini, Situs Benteng Nibung termasuk wilayah Kabupaten Lampung Timur, yang sebelumnya merupakan wilayah Kabupaten Lampung Tengah.

Benteng Nibung bersisian dengan Way Capang. Luas areal benteng sekitar 1,5 hektar membentang dengan orientasi barat-timur. Sisi selatan dan sisi barat benteng bertemu dengan Way Capang. Pada pertemuan ini dahulu terdapat beberapa batu bergores dan beberapa lumpang batu. Batu-batu tersebut dipecah untuk pengerasan jalan. Di situs ini juga banyak terdapat pecahan gerabah dan keramik.

Batu bergores yang diperoleh di situs ini tidak utuh dan terletak di dekat Benteng Nibung. Berdasarkan bagian sisa yang ada, dapat diperkirakan batu bergores tersebut memiliki diameter lebih dari 1 meter. Sedang batu bergores yang lainnya tidak ditemukan lagi sisa bagiannya. Seperti halnya Situs Bojong, goresan yang ada merupakan alur-alur batu asah yang terdapat dalam batu monolit dengan bentuk garis-garis lurus.

- $\quad$ Situs Pugung Raharjo

Situs Pugungraharjo secara administratif termasuk wilayah Desa Pugungraharjo, Kecamatan Jabung, Kabupaten Lampung Timur. Seperti halnya situs-situs lain di Lampung, situs ini pun beberapa kali telah diteliti. Situs Pugungraharjo menempati areal seluas 
kurang lebih 30 ha. Di sebelah selatan situs terdapat aliran sungai yang menjadi batas situs. Lahan situs dikelilingi fetur berupa benteng tanah dan parit. Dengan adanya benteng tanah tersebut, areal situs terbagi menjadi tiga bagian. Lebar benteng tanah tersebut kurang lebih $5 \mathrm{~m}$, sedangkan tingginya berkisar 2-3 m. Di bagian luar benteng terdapat parit yang lebarnya antara 3-5 m.

Batu bergores di Pugungraharjo diperoleh di keseluruhan bagian situs. Tinggalan arkeologis yang terdapat pada bagian pertama berupa batu berlubang, batu bergores, dan punden berundak. Pada bagian kedua terdapat susunan menhir dan batu altar yang berbentuk denah segiempat. Kedua jenis tinggalan tersebut terdapat pahatan. Pahatan salah satu menhir yang membentuk garis melingkar di kedua ujungnya. Sedang pada salah satu batu altar terdapat pahatan yang membentuk huruf T. Adapun pada bagian ketiga adalah batu berlubang, batu bergores, batu lumpang, dan punden berundak. Selain di lokasi yang telah disebutkan, temuan batu bergores juga diperoleh di mata air. Pada lokasi ini terdapat batu bergores, batu lumpang, dan batu berlubang. Seperti halnya temuan batu bergores di Situs Bojong dan Benteng Nibung, di situs ini batu bergores juga berupa batu monolit yang terdapat alur-alur bekas asahan dengan bentuk garis lurus.

- Situs Pekon Balak

Situs ini termasuk wilayah Desa Pekon Balak, Kecamatan Perwakilan Batu Brak, Kecamatan Belalau, Kabupaten Lampung Barat (Yondri, 1997/1998).
Situs ini merupakan lahan yang berada di sekitar Desa Pekon Balak. Temuan yang ada berupa dolmen, batu bergores, dan batu datar.

Batu bergores ditemukan di lokasi pemakaman umum Desa Pekon Balak. Batu bergores berbentuk garis lurus yang merupakan alur-alur asahan benda tajam. Goresan tersebut berada di bagian permukaan dengan penggoresan di segala sisi. Secara keseluruhan goresan tersebut tidak memperlihatkan bentuk tertentu. Jumlah goresan sekitar 23 goresan.

\section{- Situs Batu Kenyangan}

Situs ini merupakan bagian dari wilayah Desa Pekon Belak. Di situs ini terdapat dolmen, menhir, susunan batu melingkar, dan dolmen bergores (Yondri, 1997/1998).

Batu bergores yang ada merupakan dolmen dengan ukuran luas permukaan cukup besar. Dolmen ini ditopang oleh 5 buah batu pemyangga yang diletakkan tidak berpola. Batu bergores berbentuk garis lurus yang merupakan alur-alur asahan benda tajam. Goresan tersebut berada di bagian permukaan dengan penggoresan di segala sisi. Secara keseluruhan goresan tersebut tidak memperlihatkan bentuk tertentu.

\section{- $\quad$ Situs Air Ringkih}

Situs Air Ringkih secara administratif termasuk wilayah Ujungjaya, Desa Bungin, Kecamatan Sumberjaya, Kabupaten Lampung Barat. Kondisi Situs merupakan tanah perbukitan, di sisi meander Sungai Ringkih, pada ketinggian $865 \mathrm{~m}$ di atas 
permukaan air laut (Indraningsih, 1985: 5--7).

Situs ini merupakan kompleks dolmen dan menhir. Secara rinci terdiri dari 7 dolmen, 2 batu bergores, 6 batu yang diperkirakan menhir, 5 dolmen dalam posisi rebah, dan 1 batu tegak yang patah bagian atasnya. Batu bergores merupakan batu monolit, yang bagian permukaan terdapat garis-gari lurus bekas alur asahan.

\section{- Situs Cabangdua}

Secara administratif berada di wilayah Desa Purawiwitan, Kecamatan Sumberjaya, Kabupaten Lampung Barat. Situs ini berbentuk memanjang sekitar 173 meter. Temuan yang diperoleh berupa dolmen, dolmen bergores, gerabah, dan keramik. Identifikasi yang dilakukan, keramik berasal dari Cina abad ke-16--17.

Batu bergores di situs ini merupakan dolmen, hampir keseluruhan permukaan batu penutup dolmen terlihat torehan yang berupa garis-garis. Hasil torehan berupa bentuk asahan benda tajam. Bentuk dari goresan berupa garis lurus dan garis melengkung.

- Situs Sukarame

Situs Sukarame secara administratif berada di Desa Sukarame, Kelurahan Bawang, Kecamatan Balik Bukit, Kabupaten Lampung Barat. Situs merupakan ladang dan dikelilingi parit yang cukup dalam. Temuan yang diperoleh adalah pecahan gerabah, keramik yang diidentifikasi berasal dari Dinasti Ming, manik-manik. Selain itu juga diperoleh sebuah batu bergores.
Batu bergores di situs ini merupakan batu datar. Goresan yang ada terletak di bagian permukaan. Bentuk goresan berupa garis-garis (Sukendar, 1984: 8).

\section{FUNGSI DAN PERANAN BATU BERGORES}

Pada waktu kebudayaan megalitik berlangsung dengan saat ditemukan terdapat kesenjangan waktu. Dalam mengungkap keberadaan, fungsi, maupun peranan sangat mungkin terjadi penafsiran yang tidak tepat atau bahkan keliru. Beberapa pendekatan sudah banyak dilakukan para ahli dalan mengungkap kehidupan megalitik masa lalu. Tulisan inipun mencoba mengungkap tentang fungsi dan peranan batu bergores dengan pendekatan simbol.

Leslie White mendefinisikan simbol sebagai "a thing the value or meaning of which is bestowed upon by those who use it". Dengan demikian simbol merupakan sesuatu yang nilai atau maknanya diberikan oleh mereka yang mempergunakannya. Dengan demikian makna atau nilai tersebut tidak berasal dari atau ditentukan oleh sifat-sifat yang secara intrinsik terdapat di dalam bentuk fisiknya. Makna suatu simbol, hanya dapat ditangkap melalui cara-cara non sensorik; melalui cara-cara simbolis (Kamanto, 1993: 43 -- 45).

Munculnya bahasa simbol, menurut Herbert Blumerm, terdapat tiga pokok pikiran. Pertama bahwa manusia bertindak (act) terhadap sesuatu (thing) atas dasar makna (meaning) yang dipunyai sesuatu tersebut baginya. Kedua, makna yang dipunyai sesuatu tersebut berasal atau muncul dari interaksi seseorang 
dengan sesamanya. Ketiga makna yang diperlakukan atau diubah melalui suatu proses penafsiran (interpretative process) (Kamanto, 1993: 43 -- 45).

Sejalan dengan itu, Victor Turner mengungkap makna simbol atau perbuatan simbolik diperlukan suatu interpretasi, yang dapat dilakukan melalui tiga tahapan sebagai berikut (Sudarmadi, 1994: 87 -88).

a. Tingkat makna eksegetik (exegetical meaning)

Interpretasi dalam tahap ini bersumber dari informan, yang memahami seluk beluk simbol tersebut.Dengan demikian tahapan ini mengacu pada penafsiran informan ditambah dengan interpretasi pada mitos-mitos yang ada.

b. Tingkat makna operasional (operational meaning)

Pada tahap selanjutnya, interpretasi dilakukan oleh peneliti berdasarkan pengamatannya terhadap masyarakat yang menggunakan simbol tersebut. Pada tahap ini perlu dilihat dalam rangka kegiatan apa simbol-simbol tersebut dipakai.

c. Tingkat makna posisional (positional meaning)

Simbol akan dapat diketaui maknannya berdasarkan pemahaman unsur-unsur keseluruhan simbol tersebut. Hal tersebut berkaitan dengan simbol yang sering memiliki berbagai ragam makna (polysemi/multivocal) sehingga dengan memahami makna keseluruhannya dapat diketahui makna yang lebih diutamakan.

Fungsi dan peranan batu bergores dalam tradisi megalitik di kawasan Lampung dapat dipahami dengan menggunakan teori tiga tingkat yang telah disebut itu. Derajat penyimpangan dari penerapan teori akan sangat kecil. Hal ini didasarkan pada pemahaman bahwa pendirian bangunan megalit adalah sama, yaitu kepercayaan terhadap orang yang telah meninggal, arwahnya tetap dan mengawasi serta melindungi masyarakat yang ditinggal. Dengan demikian menjaga hubungan dengan alam roh harus terjaga dengan cara melakukan pemujaan terhadap arwah leluhur (Soejono, 1990: 212 -- 214).

\section{TINGKAT MAKNA EKSEGETIK}

Situs-situs megalitik di Kawasan Lampung merupakan situs kategori "dead monument". Dengan demikian situs megalitik tersebut sudah tidak terdapat aktivitas yang berkait dengan tradisi megalitik.Informasi tentang kehidupan megalitik hanya diperoleh dari pendapat ahli-akhli megalitik. Temuan batu bergores di kawasan Lampung biasanya merupakan temuan yang berasosiasi dengan jenis tinggalan megalitik lain. Dengan demikian dalam tingkat ini, diperlukan informasi tentang menhir, dolmen, batu datar, dan batu berurut.

Menhir berupa sebuah batu tegak yang sudah atau belum dikerjakan dan diletakkan dengan sengaja di suatu tempat untuk memperingati orang yang telah mati. Benda tersebut dianggap sebagai medium penghormatan, menampung kedatangan roh dan sekaligus menjadi lambang dari orang-orang yang diperingati (Soejono, 1990: 213).

Dolmen biasanya berbentuk batu datar monolit yang disangga oleh empat atau lebih tiang batu. Dolmen menurut beberapa ahli (Perry, 1923; Hoop, 
1932) merupakan penguburan. Adapun menurut van Hekeeren (1955), dolmen ada hubungannya dengan penguburan. Dolmen merupakan tempat yang digunakan dalam upacara pemujaaan kepada arwah leluhur. Berdasarkan beberapa penggalian yang dilakukan Balai Arkeologi Bandung di Batuberak dan sekitarnya, menunjukkan dolmen bukan merupakan suatu kuburan, tetapi ada hubungannya dengan penguburan, terutama pada pemujaaan kepada arwah leluhur (Saptono, 1994/1995: 13).

Menurut Kaudern yang dikutip oleh Haris Sukendar (1979: 15), batu bergores merupakan alat yang dipergunakan sebagai sarana pemberian kekuatan gaib terhadap suatu alat (senjata tajam) seperti pisau dan parang yang akan digunakan, yaitu dengan jalan mengasahkan alat pada batu tersebut.

\section{TINGKAT MAKNA OPERASIONAL}

Penggunaan batu bergores oleh beberapa suku di wilayah Indonesia masih dilakukan. Masyarakat di Desa Woro (Rembang) menggunakan batu asah sebagai sarana pemberian kekuatan gaib terhadap parang atau pisau yang akan digunakan untuk membunuh musuh. Dengan jalan mengasahkan parang atau pisau ke batu tersebut maka orang itu dalam rencana membunuh musuhnya akan berhasil dengan baik. Ditambahkan juga apabila parang atau pisau yang telah diasah tadi tidak dipergunakan, maka orang yang bersangkutan akan terbunuh oleh parang atau pisau itu juga (Sukendar, 1979: 15).

Temuan batu bergores di Desa Takirin, Timor merupakan tradisi yang masih berlanjut. Di desa ini jika akan dilaksanakan pertempuran dengan suku lain, senjata para pahlawan satu per satu harus diasah pada batu bertuah tersebut. Diharapkan senjata akan memperoleh kesaktian yang luar biasa dan akhirnya dapat membunuh semua musuhnya (Sukendar, 1997/1998: 64 -- 65).

\section{TINGKAT MAKNA POSISIONAL}

Pengamatan yang dilakukan pada asosiasi temuan batu bergores, yaitu menhir, dolmen, batu berurut, dan batu datar menunjukkan bahwa batu bergores berkait dengan pemujaan. Torehan yang dilakukan pada batu bergores sebagai visualisasi dari konsep pengagungan arwah leluhur. Dengan kata lain torehan yang dilakukan merupakan interaksi antara yang hidup dengan leluhur untuk mendapatkan kekuatan.

\section{SIMPULAN}

Batu bergores yang diperoleh kawasan Lampung, secara kuntitatif sangat sedikit dibanding jenis temuan megalitik lainnya. Fungsi dan peranan batu bergores di kawasan Lampung sangat berkait dengan pemujaan. Hal ini diperlihatkan dengan asosiasi temuan lainnya, yaitu menhir, dolmen, batu datar, dan batu berurut. Keinginan dan pengharapan dari pendukung budaya megalitik untuk mendapatkan kekuatan dari arwah leluhur memperlakukan batu bergores sebagai salah satu pelengkap dalam sarana pemujaan selain jenis megalitik lain. Bentuk visualisasi dari interaksi yang dilakukan dengan arwah leluhur dituangkan dalam bentuk goresan. 


\section{DAFTAR PUSTAKA}

Falah, W. Anwar. 1994. Penelitian Tradisi Megalitik di Situs Bojong Lampung Tengah. Jurnal Balai Arkeologi Bandung Edisi Perdana: 25 -- 40.

Indraningsih, Ratna J. et al.,1985. Laporan Penelitian Arkeologi di Lampung. Berita Penelitian Arkeologi No. 33. Jakarta : Pusat Penelitian Arkeologi Nasional.

Soejono, R.P (ed.). 1990. Jaman Praserah di Indonesia. Dalam Marwati Djoened Poesponegoro dan Nugroho Notosusanto. Sejarah Nasional Indonesia I. Jakarta: Departemen Pendidikan dan Kebudayaan. PN. Balai Pustaka.

Sudarmadi, Tular. 1994. Kajian Ulang Fungsi Situs Megalitik Terjan: Tinjauan Aspek Simbolik. Jejak-Jejak Budaya (Persempahan Untuk Prof. Dr. R.P. Soejono) : 83 - 100. Yogyakarta: Asosiasi Prehistori Indonesia Rayon II.

Sukendar, Haris.1979. Laporan Penelitian Kepurbakalaan Daerah Lampung. Berita Penelitian Arkeologi No. 20. Jakarta: Pusat Penelitian Arkeologi Nasional.

Sukendar, Haris. 1997/1998. Batu Bergores Sebagai Simbol Religius. Kebudayaan(13/Th. VII) Edisi Khusus: $59-69$.

Sukendar Haris, et al.,. 1984. A. Survei di Daerah Lampung B. Survei di Daerah Sumatera Selatan. Berita Penelitian Arkeologi No. 2. Jakarta: Pusat Penelitian Arkeologi Nasional.

Sunarto, Kamanto. 1993. Pengantar Sosiologi. Jakarta: Lembaga Penerbit Fakultas Ekonomi. Universitas Indonesia.

Triwuryani, R.R. 1996. Pola Persebaran Situs Benteng di Sepanjang DAS Sekampung: Ditinjau dari Kajian Wilayah. Makalah dalam Evaluasi Hasil Penelitian Arkeologi. Ujung pandang 20-26 September 1996.

Yondri, Lutfi. 1997/1998. Laporan Hasil Penelitian Arkeologi di Situs Kenyangan dan sekitarnya, Desa Pekon Balak, Kecamatan Belalau, Kab. Lampung Barat, Prop. Lampung. Laporan Hasil Penelitian Arkeologi. Bandung: Balai Arkeologi Bandung. 